\title{
STUDI KERAGAMAN GENETIK Diospyros rumphii Bakh DI SULAWESI UTARA BERDASARKAN PENANDA ISOENZIM
}

Study on genetic diversity of Diospyros rumphii Bakh

in North Sulawesi based on isoenzym markers

\author{
Julianus Kinho ${ }^{1}$, Moh. Na'iem², dan Sapto Indrioko ${ }^{2}$ \\ ${ }^{1}$ Balai Penelitian Kehutanan Manado \\ Jl. Raya Adipura Kima Atas Mapanget, Manado, Indonesia \\ email: ragilkinho@gmail.com \\ ${ }^{2}$ Fakultas Kehutanan, Universitas Gadjah Mada \\ Jl. Agro No. 1, Bulaksumur, Sleman, Yogyakarta, Indonesia
}

Tanggal diterima: 14 Juni 2016, Tanggal direvisi: 27 Juni 2016, Disetujui terbit: 15 Desember 2016

\begin{abstract}
Diospyros rumphii Bakh. is one of tropical commerciall wood species grouped in ebony. Ebony is the name of some species of commercial timber from genus of Diospyros (Ebenaceae). Seven species of them are commercial wood, which in the trade is known as ebony namely; D.celebica, D.rumphii, D.pilosanthera, D.lolin, D.ebenum, D.ferrea and D.macrophylla. Two of seven species ebony have the highest economic values namely; D.celebica and D.rumphii. Nowadays, the population D. rumphii in the nature are decreases due to over harvesting in the past. This study aims to determine genetic diversity of D. rumphii within populations, between populations and its relationship. The samples of D. rumphii in this study from four populations in North Sulawesi i.e Bitung, Talise, Talaud and Bolaang Mongondow. Genetic diversity was detected by isoenzym markers with seven enzyme i.e Glutamate oxaloacetate transmirase (GOT), Shikimate dehydrogenase (SHD), Esterase (EST), Acid phoshatase $(A C P)$, Diaphorase (DIA), 6-Phosphogluconate dehydrogenase (6PG) and Glutamate dehydrogenase (GDH). The results showed that there are three enzym was detected polymorphisme i.e EST, GOT and GDH. Genetic diversity generated by three enzyme systems who are controlled by 5 loci and 15 alleles. The average percentage of polymorphic loci was $100 \%$. The number of total genetic diversity is 0.64 ,which are distributed within population 0.59 (91.24\%) and between population 0.05(8.76\%). Cluster analysis using Unweighted Pair Group Method with Aritmatic Means (UPGMA) based on Nei standard genetic distance showed three clusters:Bitung and Bolaang Mongondow, Talise, and Talaud.
\end{abstract}

Keywords: Diospyros rumphii, isoenzym, population, genetic diversity

\begin{abstract}
ABSTRAK
Diospyros rumphii Bakh merupakan salah satu jenis kayu komersil tropis yang tergabung dalam kelompok kayu eboni. Kayu eboni adalah sebutan dari beberapa jenis kayu komersil yang berasal dari genus Diospyros (Ebenaceae). Tujuh jenis di antaranya merupakan jenis komersil, yang dalam perdagangan dikenal sebagai kayu eboni yaitu $D$. celebica, D. rumphii, D. pilosanthera, D. lolin, D. ebenum, D. ferrea, dan D. macrophylla. Dua jenis yang terpenting di antara tujuh jenis Diospyros tersebut adalah $D$. celebica dan D. rumphii yang memiliki nilai ekonomi yang lebih tinggi. Pemanenan yang dilakukan secara berlebihan pada masa lalu merupakan salah satu penyebab kelangkaan populasi $D$. Rumphii pada hutan-hutan alam di Sulawesi Utara saat ini. Penelitian ini bertujuan untuk mengetahui keragaman genetik D. Rumphii di dalam populasi, antar populasi dan hubungan kekerabatannya. Sampel D. rumphii dalam penelitian ini berasal dari empat populasi di Sulawesi Utara yaitu Bitung, Talise, Talaud, dan Bolaang Mongondow. Keragaman genetik dideteksi menggunakan penanda isoenzim dengan tujuh sistem enzim yaitu Glutamate oxaloacetate transmirase (GOT), Shikimate dehydrogenase (SHD), Esterase (EST), Acid phoshatase (ACP), Diaphorase (DIA), 6-Phosphogluconate dehydrogenase (6PG) dan Glutamate dehydrogenase (GDH). Hasil penelitian menunjukkan bahwa hanya tiga sistem enzim yang dapat mendeteksi polimorfisme yaitu GOT, EST dan GDH. Keragaman genetik yang dihasilkan oleh ketiga sistem enzim ini dikendalikan oleh 5 lokus dan15 alel. Rata-rata persentase lokus polimorfis sebesar $100 \%$. Total keragaman genetik $\left(\mathrm{H}_{\mathrm{T}}\right)$ sebesar 0,64 yang terdistribusi dalam populasi sebesar 0,59 $(91,24 \%)$ dan antar populasi 0,05 (8,76\%). Analisis klaster Unweighted Pair Group Methode with Aritmatic Mean Analysis (UPGMA) berdasarkan standar jarak genetik Nei menunjukkan bahwa terbentuk tiga klaster yaitu klaster pertama terdiri dari populasi Bitung dan Bolaang Mongondow, klaster kedua populasi Talise dan klaster ketiga populasi Talaud yang terpisah jauh dari populasi lainnya.
\end{abstract}

Kata kunci: Diospyros rumphii, isoenzim, populasi, keragaman genetik 


\section{PENDAHULUAN}

Kayu eboni merupakan sebutan dari beberapa jenis kayu komersil yang berasal dari genus Diospyros yang tergabung dalam famili Ebenaceae. Tujuh jenis Diospyros diantaranya merupakan jenis komersil, yang dalam perdagangan kayu dikenal sebagai kayu eboni yaitu: D. celebica, D. rumphii, D. pilosanthera, $D$. lolin, D. ebenum, D. ferrea dan D. macrophylla (Alrasyid, 2002). Dua jenis kayu eboni yang memiliki nilai ekonomis paling tinggi diantara ketujuh jenis tersebut adalah $D$. celebica dan D. rumphii karena memiliki ornamen kayu berupa strip dengan motif yang khas dan indah sehingga menambah nilai artistik dari produk yang terbuat dari kedua jenis kayu tersebut yang dipasaran dunia dikenal dengan nama eboni Makassar, eboni bergaris atau coromandel (Alrasyid, 2002), sehingga kedua jenis tersebut dieksploitasi secara besar-besaran pada masa lalu.

Penyebaran alami dua jenis eboni yang memiliki nilai ekonomis paling tinggi (D. celebica dan D. rumphii) sangat terbatas. Penyebaran alami $D$. celebica meliputi wilayah Sulawesi Utara, Sulawesi Tengah dan Sulawesi Selatan (Whitten et al., 1987; Sunaryo, 2002; Martawijaya, \& Kartasujana, 1977), sedangkan penyebaran D. Rumphii meliputi: semenanjung utara Pulau Sulawesi (Bolaang Mongondow, Bitung, Talise, Sangihe, Talaud) dan semenanjung utara kepulauan Halmahera di Pulau Morotai (Alrasyid, 2002; Kinho, 2014). Menurut Sunaryo (2002), disebutkan bahwa stok tegakan eboni di Sulawesi Utara (20\%), Sulawesi Tengah (65\%) dan Sulawesi Selatan (15\%).

Populasi kayu eboni di alam saat ini belum diketahui secara pasti karena belum tersedia informasi terbaru. Pemanenan yang dilakukan secara berlebihan pada masa lalu merupakan salah satu penyebab kelangkaan populasi dari jenis D. rumphii pada hutan-hutan alam di Sulawesi Utara saat ini, sehingga diperlukan upaya-upaya dalam rangka pelestarian sumberdaya genetiknya. Upaya pelestarian sumberdaya genetik $D$. rumphii dapat dilakukan melalui kegiatan konservasi in situ maupun ex situ. Untuk menunjang upaya konservasi in situ maupun ex situ, perlu diketahui keragaman atau variasi genetiknya. Penelitian ini bertujuan untuk mengetahui keragaman genetik D. rumphii didalam populasi, antar populasi dan hubungan kekerabatannya di Sulawesi Utara.

\section{BAHAN DAN METODE}

A. Bahan

Bahan yang digunakan dalam penelitian ini adalah sampel daun anakan $D$. rumphii yang berasal dari 4 populasi di Sulawesi Utara meliputi Bitung, Talise, Talaud dan Bolaang Mongondow (Gambar 1). Setiap populasi dipilih minimal 20 pohon induk, dengan jarak antar pohon induk minimal $100 \mathrm{~m}$. Setiap pohon induk diwakili oleh satu anakan. Jumlah pohon induk yang dipilih secara acak dari seluruh populasi sebanyak 119 pohon.

\section{B. Metode}

\section{Analisis isoenzim}

Prosedur kerja dalam penelitian ini mengacu pada (Seido K, 1993). Daun muda dari setiap sampel diambil $\pm 100 \mathrm{mg}$, diekstraksi menggunakan $0,1 \mathrm{ml}$ extract buffer, kemudian disentrifugasi selama 20 menit dengan kecepatan 15.000 rpm pada suhu $0^{\circ} \mathrm{C}$, sampai terbentuk dua bagian yang terpisah, yaitu larutan bening yang disebut supernatant yang digunakan dalam penelitian ini, sedangkan endapan (pellet) tidak digunakan. Gel polyacrilamide yang terdiri atas running gel (kepekatan 7,5\%) dan spacer gel (kepekatan 3,75\%) disiapkan. Supernatant dimasukkan sebanyak 10-20 $\mu 1$ untuk tiap lubang sampel pada spacer gel. Tujuh sistem enzim yang digunakan yaitu Glutamate oxaloacetate transmirase (GOT), Shikimate dehydrogenase (SHD), Esterase (EST), Acid phoshatase (ACP), Diaphorase (DIA), 6-Phosphogluconate dehydrogenase (6PG) dan Glutamate dehydrogenase (GDH). 


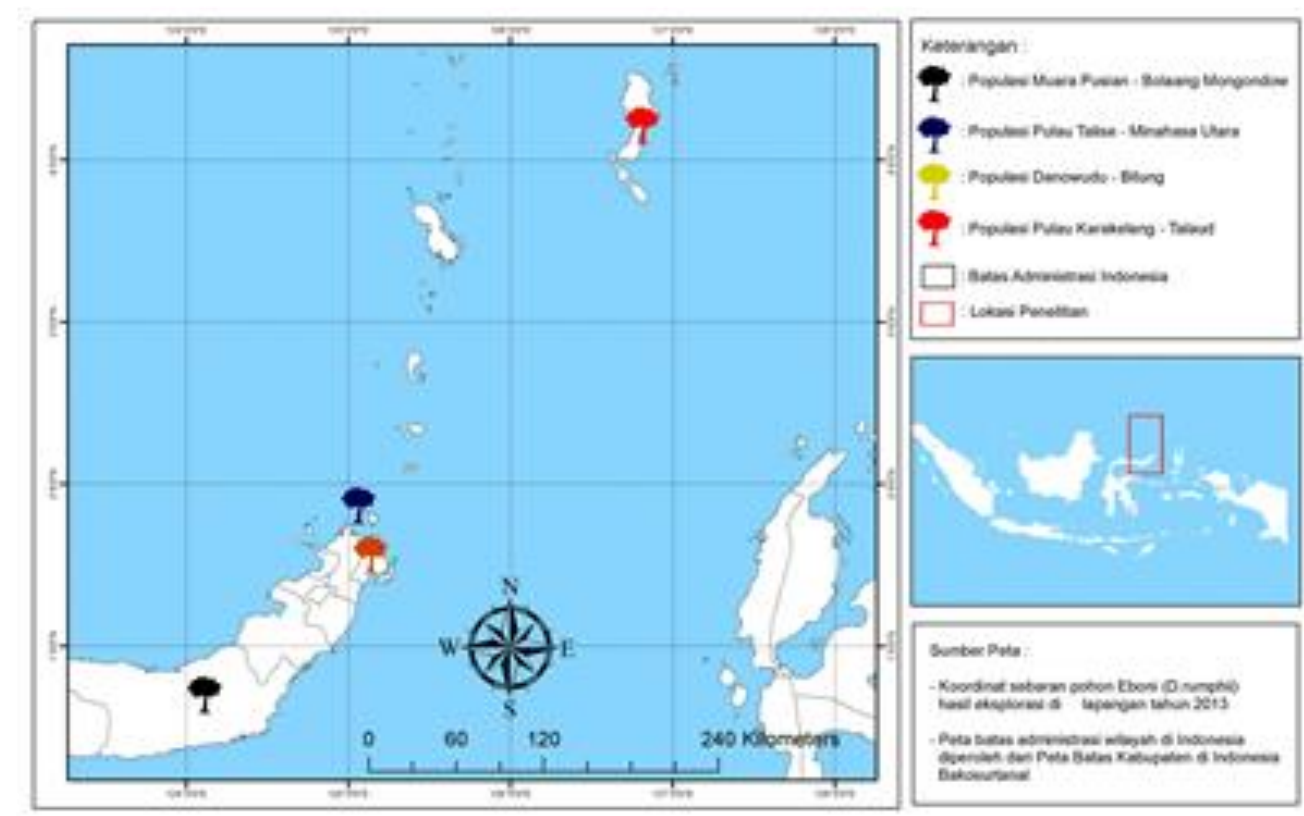

Gambar 1. Peta lokasi penelitian

Proses elektroforesis berlangsung pada suhu $4^{0} \mathrm{C}$ selama $180-200$ menit dengan arus listrik sebesar $100 \mathrm{~mA}$. Gel diwarnai dengan larutan staining kemudian difiksasi, dikeringkan dan disimpan dengan menambahkan identitas pada masing-masing gel berupa nama sampel, populasi, tanggal elektroforesis, sistem enzim yang digunakan dan nomor sampel. Tahap terakhir adalah observasi gel. Observasi gel dilakukan dengan memberi kode alel untuk setiap lokus pada pita-pita (band) yang terdapat pada lembar gel. Posisi band ditentukan oleh masing-masing nilai Rf. Nilai Rf merupakan jarak rasio antara permukaan gel dengan posisi band dan posisi bromophenol blue.

\section{Analisis data}

Parameter keragaman genetik yang diukur meliputi rata-rata jumlah alel per lokus (A/L), jumlah alel efektif per lokus (Ae), persentase lokus polimorfik (PLP), heterozigositas teramati (Ho), Heterozigositas harapan (He). Semua parameter dihitung dengan program komputer POPGENE 1.32 (Yeh, 2000). Jarak genetik dihitung berdasarkan jarak genetik standar Nei (Nei, 1972) dan koefisien diferensiasi genetik $\left(\mathrm{G}_{\mathrm{ST}}\right)$ dihitung berdasarkan pengukuran Nei (Nei, 1987). Hubungan kekerabatan antar populasi digambarkan melalui dendrogram dari analisis klaster Unweighted Pair Group Method With Arithmatic Mean (UPGMA) berdasarkan jarak genetik standar Nei.

\section{HASIL DAN PEMBAHASAN}

\section{A. Hasil}

\section{Pewarisan pola pita (inheritance of banding pattern)}

Analisis pra isoenzim yang dilakukan dalam penelitian ini menggunakan tujuh sistem enzim yaitu Glutamate oxaloacetate transmirase (GOT), Shikimate dehydrogenase (SHD), Esterase (EST), Acid phoshatase (ACP), Diaphorase (DIA), 6-Phosphogluconate dehydrogenase (6PG) dan Glutamate dehydrogenase (GDH), menunjukkan bahwa hanya tiga sistem enzim yang dapat mendeteksi lokus polimorfik untuk jenis D. rumphii yaitu EST, GOT, dan GDH. Keragaman genetik yang dihasilkan oleh ketiga sistem enzim ini dikendalikan oleh 5 lokus dan 15 alel. Jumlah alel dari masing-masing sistem enzimyaitu tiga alel per lokus. Adapun jumlah alel dan nilai $\mathrm{Rf}$ masing-masing zona dan lokus dapat dilihat pada Tabel 1. 
Tabel 1. Jumlah alel dan nilai Rf untuk setiap sistim enzim pada D. rumphii

\begin{tabular}{cccccc}
\hline \multirow{2}{*}{ Sistem Enzim } & \multirow{2}{*}{ Lokus } & \multirow{2}{*}{ Jumlah Alel } & \multicolumn{3}{c}{ Rf masing-masing alel } \\
\cline { 4 - 6 } EST & Est-1 & 3 & 31 & b & a \\
& Est-2 & 3 & 49 & 54 & 53 \\
\multirow{2}{*}{ GOT } & Est -3 & 3 & 64 & 68 & 72 \\
GDH & Got -1 & 3 & 26 & 28 & 30 \\
\hline
\end{tabular}

Keterangan: Rf adalah rasio jarak antara kedudukan alel dan bromophenol blue dari dasar gel

Pada sistem enzim EST dapat diamati tiga lokus yaitu Est-1, Est-2 dan Est-3 yang dikontrol oleh tiga alel dan dijumpai pada semua populasi. Sistem enzim GOT dapat diamati satu lokus yaitu Got-1 yang dikontrol oleh tiga alel dan dijumpai pada semua populasi. Sistem enzim GDH dapat diamati satu lokus yaitu $G d h-1$ yang dikontrol oleh tiga alel dan dijumpai pada semua populasi yang diamati.

\section{Keragaman genetik dalam populasi}

Frekuensi alel bervariasi pada masingmasing lokus dari keempat populasi D. rumphii seperti ditampilkan pada Tabel 2. Jumlah alel yang teridentifikasi pada 119 individu yang berasal dari empat populasi $D$. rumphii sebanyak 15 alel yang terdistribusi pada 5 lokus polimorfik.

Tabel 2. Frekuensi alel pada lokus polimorfik dari empat populasi D. rumphii di Sulawesi Utara.

\begin{tabular}{lccccc}
\hline Lokus & Alel & \multicolumn{3}{c}{ Populasi } \\
\hline Est-1 & & Bitung & Talise & Talaud & Bolaang Mongondow \\
& $\mathrm{a}$ & 0,73 & 0,66 & 0,67 & 0,58 \\
& $\mathrm{~b}$ & 0,19 & 0,22 & 0,23 & 0,32 \\
Est 2 & $\mathrm{c}$ & $\left.0,07^{*}\right)$ & 0,11 & $\left.0,09^{*}\right)$ & 0,10 \\
& $\mathrm{a}$ & 0,52 & 0,36 & 0,58 & 0,45 \\
& $\mathrm{~b}$ & 0,18 & 0,36 & 0,21 & 0,28 \\
& $\mathrm{c}$ & 0,29 & 0,26 & 0,20 & 0,26 \\
Est -3 & $\mathrm{a}$ & 0,18 & 0,19 & 0,40 & 0,25 \\
& $\mathrm{~b}$ & 0,34 & 0,38 & 0,25 & 0,35 \\
& $\mathrm{c}$ & 0,46 & 0,41 & 0,34 & 0,39 \\
Got-1 & $\mathrm{a}$ & 0,31 & 0,50 & 0,36 & 0,42 \\
& $\mathrm{~b}$ & 0,34 & 0,26 & 0,33 & 0,36 \\
& $\mathrm{c}$ & 0,34 & 0,23 & 0,29 & 0,22 \\
Gdh-1 & $\mathrm{a}$ & 0,34 & 0,25 & 0,26 & 0,43 \\
& $\mathrm{~b}$ & 0,61 & 0,65 & 0,44 & 0,52 \\
& $\mathrm{c}$ & $0,04^{*}$ & 0,10 & 0,28 & $0,04 *)$ \\
\hline
\end{tabular}

Keterangan: *)=Alel langka $($ frekuensi $<0,1)$

Parameter keragaman genetik dalam populasi meliputi rata-rata jumlah alel per lokus $(\mathrm{A} / \mathrm{L})$, rata-rata jumlah alel efektif per lokus
(Ae), persentase lokus polimorfik (PLP), heterozigositas teramati (Ho), Heterozigositas 
harapan $(\mathrm{He})$ dan Indeks fiksasi $\left(\mathrm{F}_{\mathrm{IS}}\right)$ ditampilkan pada Tabel 3.

Tabel 3. Ringkasan keragaman genetik empat populasi D. rumphii di Sulawesi Utara

\begin{tabular}{lcccccc}
\hline Populasi & A/L & Ae & PLP $(\%)$ & Ho & He & F \\
\hline Bitung & 3,00 & 2,39 & 100 & 0,54 & 0,56 & 0,03 \\
Talise & 3,00 & 2,47 & 100 & 0,52 & 0,58 & 0,09 \\
Talaud & 3,00 & 2,60 & 100 & 0,40 & 0,60 & 0,32 \\
Bolaang Mongondow & 3,00 & 2,58 & 100 & 0,56 & 0,60 & 0,07 \\
Rata-rata & $\mathbf{3 , 0 0}$ & $\mathbf{2 , 5 1}$ & $\mathbf{1 0 0}$ & $\mathbf{0 , 5 1}$ & $\mathbf{0 , 5 9}$ & $\mathbf{0 , 1 3}$ \\
\hline
\end{tabular}

Jumlah alel per lokus (A/L) 3,00 pada semua populasi yang diteliti. Jumlah alel efektif per lokus (Ae) berkisar antara 2,39 (Bitung) hingga 2,60 (Talaud) dengan rata-rata 2,51. Persentase Lokus Polimorfik (PLP) pada taraf kepercayaan $95 \%$ sebesar $100 \%$ pada semua populasi yang diteliti. Nilai heterozigositas teramati (Ho) berkisar antara 0,40 (Talaud) hingga 0,56 (Bolaang Mongondow) dengan ratarata sebesar 0,51. Nilai heterozigositas harapan (He) berkisar antara 0,56 (Bitung) hingga 0,60 (Bolaang Mongondow). Nilai indeks fiksasi ( $\mathrm{F}_{\mathrm{IS}}$ ) pada setiap populasi dan lokus yang diamati bernilai positif, yang mengindikasikan bahwa pada semua populasi terjadi kecenderungan pengurangan heterozigositas yang mengarah pada perkawinan kerabat (inbreeding). Populasi dengan indeks fiksasi paling kecil adalah populasi Bitung $(0,03)$ dan yang paling tinggi adalah populasi Talaud $(0,32)$.

Nilai heterozigositas harapan $(\mathrm{Hs})$ pada setiap lokus berdasarkan populasi seperti ditampilkan pada Tabel 4, berkisar antara 0,56 (Bitung) hingga 0,60 (Bolaang Mongondow) dengan rata-rata 0,59. Nilai heterozigositas observasi (Ho) pada setiap lokus berdasarkan populasi berkisar antara 0,40 (Bitung) hingga 0,56 (Bolaang Mongondow) dengan nilai ratarata sebesar 0,51 (Tabel 5).

Tabel 4. Heterozigositas harapan (Hs) berdasarkan lokus dan asal populasi

\begin{tabular}{lcccccc}
\hline \multirow{2}{*}{\multicolumn{1}{c}{ Provenans }} & \multicolumn{5}{c}{ Hs pada lokus } & \multirow{2}{*}{ Rata-rata } \\
\cline { 2 - 6 } & Est-1 & Est-2 & Est-3 & Got-1 & Gdh-1 & \\
\hline Bitung & 0,42 & 0,60 & 0,62 & 0,66 & 0,50 & 0,56 \\
Talise & 0,49 & 0,65 & 0,63 & 0,62 & 0,50 & 0,58 \\
Talaud & 0,48 & 0,57 & 0,65 & 0,66 & 0,64 & 0,60 \\
Bolaang Mongondow & 0,55 & 0,64 & 0,65 & 0,64 & 0,53 & 0,60 \\
Rata-rata & $\mathbf{0 , 4 8}$ & $\mathbf{0 , 6 2}$ & $\mathbf{0 , 6 4}$ & $\mathbf{0 , 6 5}$ & $\mathbf{0 , 5 4}$ & $\mathbf{0 , 5 9}$ \\
\hline
\end{tabular}

Berdasarkan Tabel 4 dan Tabel 5 diketahui bahwa pada semua populasi yang diteliti memiliki nilai $\mathrm{H}_{\mathrm{O}}$ yang lebih rendah dari nilai $\mathrm{Hs}$.
Hal ini mengindikasikan bahwa individu yang terdapat pada keempat populasi yang diamati tersebut lebih banyak bergenotipe homozigot. 
Tabel 5. Heterozigositas observasi (Ho) berdasarkan lokus dan asal populasi

\begin{tabular}{lcccccc}
\hline \multirow{2}{*}{ Provenans } & \multicolumn{5}{c}{ Ho pada lokus } & \multirow{2}{*}{ Rata-rata } \\
\cline { 2 - 5 } Bitung & Est-1 & Est-2 & Est-3 & Got-1 & Gdh-1 & 0,54 \\
Talise & 0,38 & 0,45 & 0,56 & 0,63 & 0,68 & 0,52 \\
Talaud & 0,38 & 0,52 & 0,72 & 0,40 & 0,60 & 0,40 \\
Bolaang Mongondow & 0,20 & 0,42 & 0,48 & 0,42 & 0,48 & 0,56 \\
Rata-rata & 0,56 & 0,47 & 0,62 & 0,56 & 0,59 & $\mathbf{0 , 5 1}$ \\
\hline
\end{tabular}

\section{Keragaman genetik antar populasi}

Keragaman genetik suatu jenis yang terbagi dalam beberapa populasi dapat ditaksir dari ferkuensi allel dalam bentuk heterozigositas harapan dalam populasi $\left(\mathrm{H}_{\mathrm{S}}\right)$ dan antar populasi (D $D_{\mathrm{ST}}$ ) yang tidak tergantung pada frekuensi genotipe (Nei, 1973). Nilai relatif dari perbedaan gen antar subpopulasi dapat diukur dengan $\mathrm{G}_{\mathrm{ST}}$ yang merupakan koefisien perbedaan gen. Nilai $\mathrm{G}_{\mathrm{ST}}$ akan menjadi identik dengan nilai $\mathrm{F}_{\mathrm{ST}}$ apabila hanya terdapat dua allel pada sebuah lokus, oleh karena itu nilai $F_{\text {ST }}$ dan $\mathrm{G}_{\text {ST }}$ dalam penelitian ini tidak identik karena terdapat tiga allel dalam satu lokus, sehingga nilai yang digunakan untuk menaksir perbedaan genetik D. rumphii di Sulawesi Utara antar populasi menggunakan nilai $\mathrm{G}_{\mathrm{ST}}$. Nilai $\mathrm{G}_{\mathrm{ST}}$ bervariasi dari 0 sampai 1 yang dapat diklasifikasikan menjadi rendah (< $0,05)$, sedang $(0,05-0,15)$, tinggi $(0,15-0,25)$ dan sangat tinggi $(>0,25)$.
Jarak genetik merupakan ukuran dari besarnya perbedaan genetik antar populasi dan berguna untuk pengelompokkan populasi. Jarak genetik standar Nei (Nei, 1972) paling banyak digunakan diantara banyak taksiran perbedaan genetik yang menggunakan frekuensi allel antar populasi. Jika sebagian besar perbedaan populasi sebagai akibat isolasi karena jarak geografis, maka jarak genetik dan jarak geografis diharapkan berkorelasi positif (Yeh, 2000). Hasil analisis menunjukkan bahwa nilai heterozigositas total untuk keempat populasi D. rumphii di Sulawesi Utara sebesar 0,64.

Nilai keragaman antar populasi $\left(\mathrm{D}_{\mathrm{ST}}\right)$ sebesar 0,05. Proporsi keragaman genetik antar populasi terhadap total keragaman genetik $\left(\mathrm{G}_{\mathrm{ST}}\right)$ di antara keempat populasi D. rumphii sebesar 0,08 . Nilai keragaman genetik antar populasi dan proporsi keragaman genetik antar populasi terhadap total populasi ditampilkan pada Tabel 6 .

Tabel 6. Nilai keragaman genetik antar populasi $\left(\mathrm{D}_{\mathrm{ST}}\right)$ dan koefisien diferensiasi populasi $\left(\mathrm{G}_{\mathrm{ST}}\right)$

\begin{tabular}{cccc}
\hline $\begin{array}{c}\text { Heterozigosita } \\
\text { s Total }\left(\mathrm{H}_{\mathrm{T}}\right)\end{array}$ & $\begin{array}{c}\text { Heterozigositas } \\
\text { Harapan }\left(\mathrm{H}_{\mathrm{S}}\right)\end{array}$ & $\begin{array}{c}\text { Keragaman Genetik } \\
\text { Antar Populasi }\left(\mathrm{D}_{\mathrm{ST}}\right)\end{array}$ & $\begin{array}{c}\text { Proporsi Keragaman Genetik Antar Populasi } \\
\text { Terhadap Total Keragaman Genetik }\left(\mathrm{G}_{\mathrm{ST}}\right)\end{array}$ \\
\hline 0,64 & 0,59 & 0,05 & 0,08 \\
\hline
\end{tabular}

Jarak genetik antar pasangan populasi disajikan pada Tabel 7. Populasi yang memiliki jarak genetik terbesar diantara keempat populasi D. rumphii yang dianalisis, adalah populasi Talise dan Talaud $(0,06)$ dan populasi yang memiliki jarak genetik terkecil adalah populasi Bitung dan Bolaang Mongondow (0,02).
Hubungan kekerabatan antar populasi digambarkan melalui dendrogram analisis klaster Unweighted Pair Group Methode with Aritmatic Mean Analysis (UPGMA) berdasarkan Nei's Standard Genetic Distance (1972) (Gambar 2). 
Tabel 7. Jarak genetik (bawah diagonal) dan identitas genetik(atas diagonal) dari 4 populasi D. rumphii berdasarkan Nei's Standard Genetic Distance (1972)

\begin{tabular}{|c|c|c|c|c|}
\hline Populasi & Bitung & Talise & Talaud & Bolaang Mongondow \\
\hline Bitung & ----- & 0,96 & 0,95 & 0,97 \\
\hline Talise & 0,03 & ----- & 0,93 & 0,97 \\
\hline Talaud & 0,04 & 0,06 & ----- & 0,95 \\
\hline $\begin{array}{l}\text { Bolaang } \\
\text { Mongondow }\end{array}$ & 0,02 & 0,02 & 0,04 & ------ \\
\hline
\end{tabular}

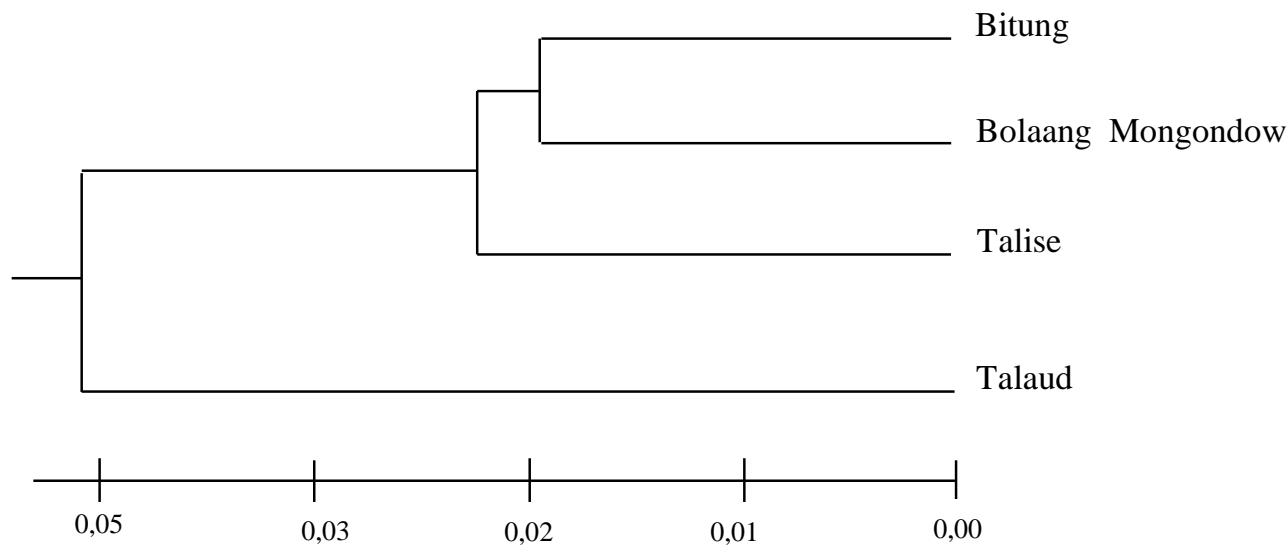

Gambar 2. Hubungan kekerabatan empat populasi D. rumphii di Sulawesi Utara berdasarkan Nei's Standard Genetic Distance (1972), dengan metode UPGMA

\section{B. Pembahasan}

\section{Pewarisan pola pita (inheritance of banding pattern)}

Pola pita dari setiap sistem enzim merupakan zona-zona aktif yang diinterpretasikan sebagai lokus. Berdasarkan hasil pengujian awal dengan tujuh sistem enzim yang digunakan diketahui bahwa enzim EST, GOT dan GDH mempunyai aktifitas tinggi dengan pola pita konsisten. Tiga sistem enzim yaitu ACP, DIA dan SHD membentuk pola pita yang tidak jelas, sedangkan sistem enzim 6PG membentuk pola pita yang jelas dan konsisten namun monomorfik sehingga tidak digunakan.

Perbedaan pola pita berkaitan langsung dengan susunan asam amino. Enzim yang menganalisis dan susunan asam amino yang membentuk protein ini disandi oleh susunan basa nukleotida dalam DNA yang khas untuk setiap jenis protein atau enzim. Oleh karena itu tidak setiap enzim akan cocok untuk suatu jenis tanaman ataupun akan terjadi polimorfisme dari setiap sistem enzim. Sebagai contoh pada hasil penelitian keragaman genetik untuk jenis meranti (Shorea leprosula) yang menggunakan tujuh sistem enzim, terdapat tiga sistem enzim yang tidak dapat digunakan untuk mendeteksi keragaman genetik pada jenis meranti (Na'iem, 2001). Seido (1993) melaporkan bahwa sistem enzim yang dapat digunakan untuk menganalisis keragaman genetik untuk tanaman kehutanan sebanyak 25 jenis yang memiliki pola pita (banding pattern) yang konsisten menggambarkan polimorfik. Penggunaan sistem enzim polimorfik akan membantu dalam 
penentuan keanekaragaman genetik (Lee et al., 2002).

\section{Keragaman genetik dalam populasi}

Rata-rata jumlah alel efektif per lokus lebih rendah dari rata-rata jumlah alel secara aktual per lokus. Hal ini mengindikasikan bahwa di dalam populasi-populasi tersebut ada sejumlah alel yang frekuensinya rendah dan sedikit mempengaruhi variasi genetik dalam populasi. Selain itu alel efektif (Ae) yang lebih rendah daripada alel aktual (A/L) juga menunjukkan terjadi perubahan frekuensi alel yang semakin berkurang. Pengurangan frekuensi alel ini dapat disebabkan oleh seleksi ataupun peluang (drift). Efek genetik bottleneck dapat terjadi karena drift secara ekstrim dan dapat dideteksi dari perubahan pada frekuensi alel (Lee et al., 2002). Hilangnya alel ini akan mengurangi perbandingan tersebut yang berakibat pada terjadinya populasi bottleneck.

Nilai rata-rata keragaman genetik dalam populasi yang ditunjukkan oleh nilai rata-rata heterozigositas harapan $(\mathrm{He})$ dari keempat populasi D. rumphii yang diteliti sebesar 0,59. Nilai ini lebih besar dari yang dilaporkan oleh Restu (2007), yang melakukan penelitian untuk eboni dari spesies yang berbeda yaitu D. celebica yang berasal dari lima provenans Sulawesi Selatan (Barru, Malili, Mamuju, Maros dan Sidrap)dengan menggunakan empat sistem enzim (EST, GOT, 6PG, GDH) dengan nilai ratarata keragaman genetik dalam populasi $(\mathrm{Hs})$ sebesar 0,22. Widyatmoko, Nurtjahjaningsih, dan Prastyono (2011) menyebutkan bahwa ratarata keragaman genetik D. celebica dalam populasi yang berasal dari tiga provenans di Sulawesi Tengah dan Sulawesi Selatan (Parigi, Wasupoda dan Mangkutana) sebesar 0,28. Nilai rata-rata keragaman genetik dalam populasi yang ditunjukkan oleh nilai heterozigositas harapan (Hs) dalam penelitian ini sebesar $(0,59)$ termasuk tinggi jika dibandingkan dengan rata-rata nilai He dari 16 spesies tumbuhan tropis seperti dilaporkan oleh Hamrick dan Godt (1990) dalam
Lestyaningsih, Nai'em dan Winarni (2005) yaitu sebesar 0,21.

Nilai heterozigositas harapan untuk keempat populasi D. rumphii di Sulawesi Utara tergolong tinggi sesuai kriteria nilai heterozigositas, bahwa nilai $\mathrm{He}>0,30$ tergolong besar, nilai $\mathrm{He}$ berkisar antara 0,20 - 0,30 tergolong sedang, dan nilai $\mathrm{He}<0,20$ tergolong rendah (Na'iem, 2001). Nilai $\mathrm{He}$ yang paling kecil ditunjukkan oleh populasi Bitung sebesar 0,56 sedangkan yang paling tinggi ditunjukkan oleh populasi Bolaang Mongondow dan populasi Talaud $(0,60)$. Hal ini mengindikasikan bahwa populasi $D$. rumphii yang ada di Sulawesi Utara, meskipun sudah terbagi dalam sub-sub populasi dan terpisah-pisah (terisolasi), namun masih menyimpan keragaman genetik yang tinggi. Hal ini diduga karena $D$. rumphii memiliki kecenderungan berkawin silang dan kemungkinan didukung oleh agen polinator yang berperan besar terhadap keberhasilan penyerbukkan. Pada kondisi yang demikian, peluang terjadinya perkawinan kerabat (inbreeding) yang tidak menguntungkan menjadi lebih kecil. Menurut Indrioko (1996), disebutkan bahwa perkawinan kerabat secara perlahan-lahan menyeleksi individu-individu dengan genotipe yang buruk, kemudian lambat laun jumlah alelnya akan semakin menurun dan akhirnya hilang dari populasi yang sangat kecil dan saling terpisah, sehingga bisa terjadi seleksi mundur (disgenic selection).

Jenis $D$. rumphii memiliki preferensi berkawin silang (outcrossing). Hasil analisis menunjukkan bahwa, variasi keragaman genetik D. rumphii dalam populasi sangat tinggi yang ditunjukkan oleh nilai Hs sebesar 0,59 (91,24\%). Hal ini sesuai dengan yang diungkapkan oleh Hamrick dan Godt (1989), bahwa jenis yang berkawin silang (outcrossing) terutama yang diserbuki oleh angin mempunyai keragaman genetik dalam populasi lebih besar dan keragaman genetik antar populasi yang rendah. Perkawinan silang (outcrossing) dapat menyebabkan terjadinya pencampuran materi 
genetik dari satu pohon induk dengan pohon induk lainnya.

Nilai rata-rata indeks fiksasi atau koefisien silang dalam $\left(\mathrm{F}_{\mathrm{IS}}\right)$ D. rumphii di Sulawesi Utara untuk semua populasi sebesar 0,13. Indeks fiksasi $D$. rumphii pada keempat populasi menunjukkan nilai > 0 , yang mengindikasikan bahwa untuk semua populasi D. rumphii di Sulawesi Utara terjadi pengurangan frekuensi alel-alel tertentu yang mempengaruhi keragaman genetik, meskipun nilai keragaman genetik dalam populasi yang ditunjukkan oleh nilai $\mathrm{He}$ maupun $\mathrm{Hs}$ tergolong tinggi $(>0,30)$. Nilai indeks fiksasi yang paling besar ditunjukkan oleh populasi Talaud $(0,32)$, disusul populasi Talise $(0,09)$, populasi Bolaang Mongondow $(0,07)$ dan yang paling rendah ditunjukkan oleh populasi Bitung (0,03). Populasi Talaud dan Talise memiliki nilai indeks fiksasi yang paling tinggi dibandingkan populasi lainnya dapat dipahami karena kedua populasi tersebut merupakan daerah kepulauan, sehingga banyak faktor yang dapat menyebabkan indeks fiksasi pada kedua populasi tersebut menjadi tinggi diantaranya yaitu karena jumlah individu pohon dewasa yang terlibat dalam perkawinan, ukuran populasi yang kecil dan waktu pembungaan yang tidak seragam diduga ikut berpengaruh menurunkan tingkat keberhasilan perkawinan silang (outcrossing) dan menyebabkan peningkatan frekuensi perkawinan kerabat (inbreeding).

Secara keseluruhan dapat dipahami bahwa keragaman genetik $D$. rumphii dari empat populasi di Sulawesi Utarapada saat ini masih dalam keadaan baik karena menyimpan keragaman genetik yang tinggi, namun indeks fiksasi yang menunjukkan kecenderungan peningkatan perkawinan kerabat (inbreeding) harus menjadi perhatian untuk dipertimbangkan dalam manajemen pengelolaan sumberdaya genetik.

\section{Keragaman genetik antar populasi}

Keragaman genetik antar populasi atau provenans dapat diukur dari besarnya nilai $\mathrm{F}_{\mathrm{ST}}$ atau $G_{\text {ST. Nilai }} G_{\text {ST }}$ paling banyak digunakan untuk mengukur perbedaan genetik antar populasi atau provenans karena tidak dipengaruhi oleh sistem reproduksi spesies, jumlah alel per lokus dan bentuk kekuatankekuatan evolusi seperti migrasi, mutasi dan seleksi. Nilai $\mathrm{G}_{\mathrm{ST}}$ bervariasi dari 0sampai 1. Menurut Nei (1973) disebutkan bahwa nilai GST dibedakan menjadi empat kelompok atau kategori yaitu; rendah $(<0,05)$, sedang $(0,050-$ $0,150)$, tinggi $(0,151-0,250)$ atau sangat tinggi (> 0,250). Berdasarkan kriteria tersebut diatas, perbedaan genetik D. rumphii antar populasi di Sulawesi Utara tergolong "sedang" yang ditunjukkan oleh nilai $\mathrm{G}_{\mathrm{ST}}$ sebesar 0,08 (8,76\%). Hal ini menunjukkan bahwa total keragaman genetik yang ada $\left(\mathrm{H}_{\mathrm{T}}\right)$ sebesar 0,64 berasal dari keragaman genetik antar populasi $8,76 \%$ sedangkan $91,24 \%$ berasal dari keragaman genetik dalam populasi. Nilai ini tidak berbeda jauh dengan hasil penelitian keragaman genetik D. celebica yang dilaporkan oleh Restu (2007), yang berasal dari lima provenans di Sulawesi Selatan (Barru, Malili, Mamuju, Maros dan Sidrap) dengan nilai $\mathrm{G}_{\mathrm{ST}}$ sebesar 0,04. Keragaman genetik D. celebica yang berasal dari lima provenans di Sulawesi Selatan sebesar 95,04\% berasal dari keragaman dalam populasi sedangkan antar populasi sebesar 4,96\%. Widyatmoko et al. (2011), melaporkan bahwa keragaman genetik $D$. celebica dari tiga porovenans di Sulawesi yang berasal dari Parigi (Sulawesi Tengah), Wasupoda dan Mangkutana (Sulawesi Selatan) sebesar 70\% terdistribusi di dalam provenans dan $30 \%$ terdistribusi antar provenans.

Nilai keragaman genetik antar populasi D. rumphii dalam penelitian ini $\left(\mathrm{G}_{\mathrm{ST}}=0,08\right)$ sedikit lebih rendah jika dibandingkan dengan rata-rata nilai $\mathrm{G}_{\mathrm{ST}}$ pohon tropis yaitu 0,10 (Lovelless, 1992 dalam Haryjanto, 2009) dan rata-rata nilai $\mathrm{G}_{\mathrm{ST}}$ tanaman tropis berumur panjang yang tersebar secara regional yaitu 0,11. Hamrick dan Godt (1989), menyebutkan bahwa tanaman tropis berumur panjang dengan sistem perkawinan silang (outcrossing) dan 
penyerbukannya dilakukan oleh binatang memiliki nilai $\mathrm{G}_{\mathrm{ST}}$ sebesar 0,09.

Perbedaan genetik antar populasi D. rumphii dalam penelitian ini yang tergolong "sedang" mengindikasikan bahwa aliran genetik (gene flow) antar populasi masih berlangsung dengan baik yang diduga dipengaruhi oleh kontribusi dari agen pollinator salah satu diantaranya yaitu kelelawar yang memiliki jangkauan terbang yang luas, selain itu karena jenis D. rumphii memiliki sistem reproduksi outcrossing. Menurut Hamrick dan Godt (1989), yang melakukan penelitian terhadap 449 jenis tumbuhan yang mewakili 165 genera menyebutkan bahwa, pada umumnya jenis tumbuhan berkayu yang penyebarannya luas, sistem reproduksinya outcrossing dan penyebaran biji luas cenderung mempunyai keragaman genetik dalam populasi lebih besar daripada keragaman genetik antar populasi. Rendahnya nilai perbedaan genetik antar populasi pada pohon tropis telah dilaporkan juga misalnya pada jenis Eucalyptus urophylla S.T. Blake sebesar 0,11 (Bell \& House, 1994 dalam Haryjanto, 2009), Intsia palembanica sebesar 0,04 (Lee et al., 2002), Intsia bijuga sebesar 0,04 (Yudohartono, 2008). Dengan struktur genetik populasi $D$. rumphii di Sulawesi Utara yang memiliki keragaman genetik sebesar 91,24\% terdistribusi di dalam populasi, maka dapat menangkap lebih dari $99 \%$ dari total keragaman genetik yang ada seperti dikemukakan oleh Hamrick (1993), bahwa untuk species tumbuhan tropis bila $80 \%$ dari total keragaman genetik terdistribusi dalam populasi, maka lima populasi sampling dianggap dapat menangkap 99\% dari total keragaman genetik yang ada.

Berdasarkan analisis klaster keempat populasi D. rumphii di Sulawesi Utara terbagi menjadi tiga klaster. Populasi Bitung dan Bolaang Mongondow membentuk klaster pertama, populasi Talise membentuk klaster kedua dan populasi Talaud membentuk klaster ketiga. Populasi Bitung dan Bolaang Mongondow yang membentuk klaster pertama dapat dipahami karena kedua populasi tersebut berada pada satu daratan di pulau utama Sulawesi, sedangkan populasi Talise dan Talaud yang membentuk klaster sendiri-sendiri karena kedua populasi tersebut berada di daerah kepulauan. Populasi Talise meskipun membentuk klaster terpisah dari klaster pertama (Bitung-Bolaang Mongondow), namun masih berdekatan dengan klaster pertama karena populasi Talise yang berasal dari Pulau Talise di Kabupaten Minahasa Utara secara geografis masih berdekatan dengan klaster pertama (Bitung-Bolaang Mongondow) yang berjarak \pm $40 \mathrm{~km}$ sebelah sebelah utara dari populasi Bitung. Populasi Talaud yang berasal dari pulau Karangetan, terpisah jauh dari klaster pertama dan klaster kedua karena secara geografis populasi ini terletak di laut Pasifik Utara yang berjarak $\pm 348,65 \mathrm{~km}$ sebelah utara dari populasi Bitung (klaster pertama) dan berjarak $\pm 319,93$ $\mathrm{km}$ sebelah utara dari populasi Talise (klaster kedua).

\section{Implikasi pada program konservasi genetik}

Nilai keragaman genetik D. rumphii yang tinggi pada keempat populasi di Sulawesi Utara yang ditunjukkan oleh nilai $\mathrm{He}$ maupun $\mathrm{Hs}$ (> 0,30), mengindikasikan bahwa tegakan D. rumphii pada sebaran alamnya masih dalam kondisi yang baik.Tujuan konservasi genetik D. rumphii lebih diarahkan untuk menjaga kemampuan evolusi jangka panjang. Menurut Jane et al., (1998) dalam Widyatmoko (2006), disebutkan bahwa tujuan utama dari pendokumentasian tingkat dan distribusi keragaman genetik suatu jenis adalah untuk mendesain strategi yang optimal untuk konservasi suatu jenis.

Hasil penelitian ini menunjukkan bahwa keragaman D. rumphii di Sulawesi Utara sebagian besar terdistribusi di dalam populasi $(91,24 \%)$, sedangkan sisanya terdistribusi di antar populasi (8,76\%). Hamrick (1993), mengusulkan bahwa untuk jenis tanaman tropis, jika lebih dari $80 \%$ dari total keragaman genetik terdistribusi dalam populasi, lima populasi yang 
ditempatkan secara strategis seharusnya dapat mempertahankan $99 \%$ dari total keragaman genetiknya, sehingga dengan keragaman genetik D. rumphii sebesar $91,24 \%$ terdistribusi di dalam populasi maka setidaknya dapat menangkap lebih dari 99\% dari total keragaman D. rumphii di Sulawesi Utara. Meskipun demikian, karena D. rumphii memiliki sistem perkawinan silang luar (outcrossing) dan variasi sifat-sifat morfologis/fenotipe dan adaptifnya belum diketahui dengan baik maka jumlah populasi yang dikonservasi seharusnya lebih dari empat populasi. Dengan mempertimbangkan tingkat dan distribusi keragaman genetik $D$. rumphii berdasarkan penanda isoenzim dan fitogeografi tumbuhan di kawasan Wallacea, maka sebaiknya materi genetik D. rumphii yang akan digunakan untuk tujuan konservasi ex situ diambil lebih dari empat populasi tersebut.

Terdapat tiga jenis Diospyros yang tergolong sebagai kayu eboni yang memiliki kemiripan morfologis yaitu D. celebica, $D$. rumphii dan $D$. lolin sehingga dalam melakukan eksplorasi materi genetic untuk tujuan konservasi sumberdaya genetic harus dilakukan secara hati-hati. Kemiripan morfologis tersebut misalnya pada penampakan permukaan batang, ketiga jenis tersebut memiliki permukaan batang berwarna hitam dan beralur seperti ditunjukkan pada Gambar 3.
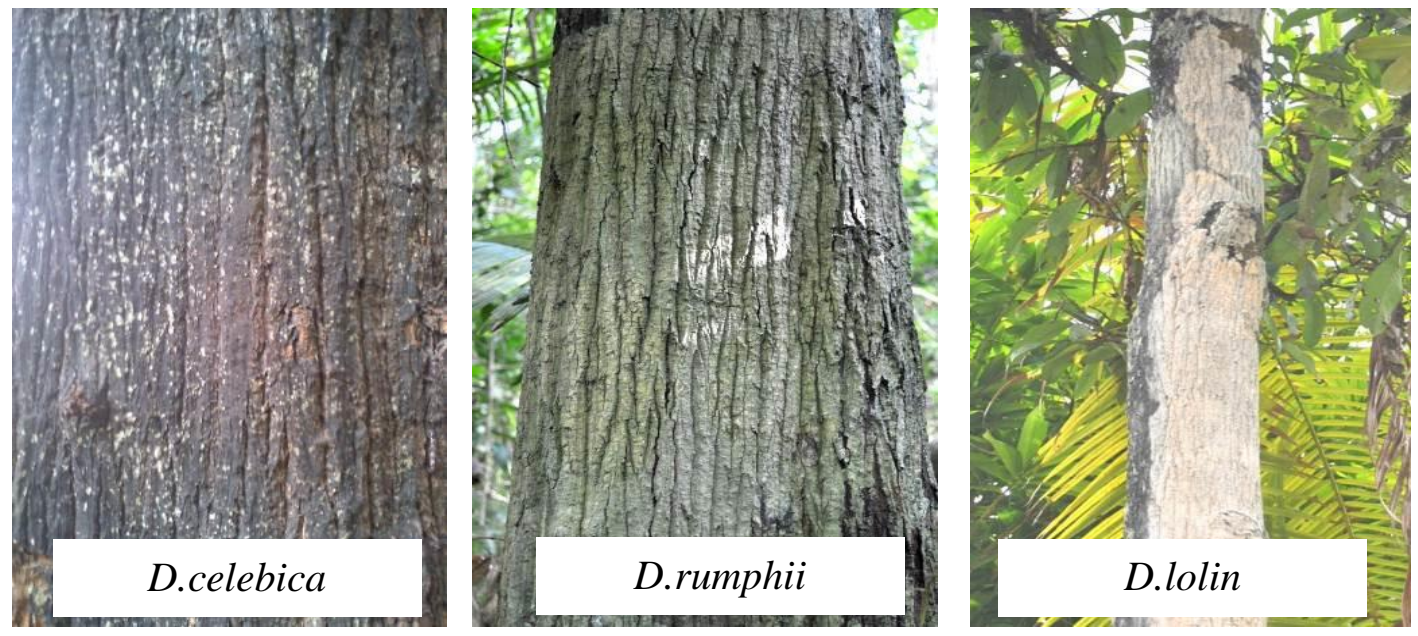

Gambar 3. Penampakan permukaan batang tiga jenis Diospyros yang memiliki kemiripan morfologis

Pengambilan populasi - populasi D. rumphii dari sebaran geografis yang diduga kemungkinan lebih banyak pada daerah kepulauan yang saling terpisah oleh lautan yang dapat menyebabkan terjadinya isolasi reproduksi perlu menjadi pertimbangan dalam program konservasi genetik $D$. rumphii. Isolasi reproduksi dan adaptasi lokal dapat menyebabkan semakin besarnya diferensiasi genetik antar populasi D. rumphii di semenanjung utara Sulawesi. Center for Plant Conservation (1991), merekomendasikan bahwa jumlah 10-50 individu per populasi merupakanjumlah yang layak antara batas minimum dan pengambilan sampel yang terlalu banyak. Yonezawa (1985) dalam Widyatmoko (2006), menganjurkan bahwa 10 individu per populasi memenuhi kriteria baik dari segi kecukupan maupun efisiensi. Meskipun tidak ada ketentuan pasti mengenai jumlah individu per populasi tetapi yang perlu diperhatikan adalah posisi antar individu. Individu-individu yang akan dijadikan sumber pengumpulan materi genetik sebaiknya agak berjauhan dengan maksud agar biji atau anakan yang dikumpulkan tidak hanya merupakan hasil perkawinan dari individuindividu yang dipilih tetapi merupakan hasil 
perkawinan lebih dari sejumlah individuindividu pohon yang terpilih.

\section{Implikasi pada program pemuliaan}

Penelitian yang terkait dengan keragaman genetik $D$. rumphii belum banyak dilakukan seperti pada jenis D. celebica. Meskipun demikian, hasil-hasil penelitian mengenai keragaman genetik $D$. celebica dapat dijadikan acuan dalam menyusun program pemuliaan D. rumphii. Hal tersebut karena tidak menutup kemungkinan dalam penelitian-penelitian keragaman genetik eboni yang dilakukan sebelumnya terjadi pencampuran materi antara D. celebica dan $D$. rumphii mengingat kedua jenis ini secara sepintas sangat mirip di alam.
Upaya-upaya dalam program pemuliaan D. rumphii sangat penting dan mendesak untuk segera dilakukan. Hal ini didasari dengan pertimbangan karena eboni $D$. rumphii merupakan jenis kayu komersil yang termasuk dalam "Kelompok Indah Satu" dalam penggelompokkan jenis kayu komersil (Departemen Kehutanan, 2003).

Koleksi materi genetik D. rumphii dan pembangunan tegakan konservasi ex situ dari hasil penelitian ini dapat dijadikan sebagai populasi dasar dalam strategi pemuliaan pohon dan menjadi tempat menyimpan genotipegenotipe tertentu yang mungkin hilang akibat seleksi yang dilakukan pada program pemuliaan (Gambar 4).

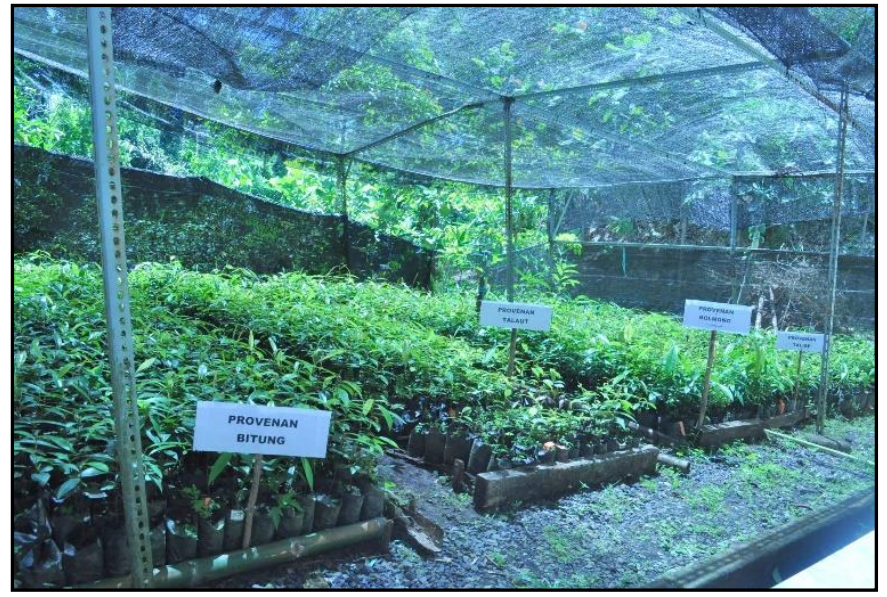

Gambar 4. Koleksi materi genetik D. rumphii di persemaian yang akan digunakan untuk pembangunan kebun konservasi ex situ

Keragaman genetik D. rumphii yang masih tinggi pada populasi Bolaang Mongondow $(\mathrm{He}=0,60)$ diharapkan dapat mendukung upaya pemuliaan jenis ini. Hal ini karena tidak semua jenis pohon memiliki korelasi antara keragaman pada penanda genetik dengan fenotipe untuk kebanyakan sifat-sifat penting secara ekonomi (Moran, \& Glaubitz, 2000). Contoh yang dapat dijadikan sebagai bahan pembelajaran dan evaluasi yaitu pada Acacia mangium yang menunjukkan adanya korelasi antara keragaman gentik dengan fenotipe, dimana pada populasi yang terisolasi (Seram \& Sidei), memiliki variasi genetik yang sangat kecil (Butcher, Moran, \&
Perkins, 1996) dan kedua populasi tersebut berdasarkan hasil uji provenans memiliki pertumbuhan yang paling lambat (Hardwood \& William, 1992 dalam Hardiyanto, 2000). Demikian pula dengan jenis Cendana seperti dilaporkan Jones (2008), bahwa keragaman genetik Cendana dari India, Timor dan Northen Teritory di Kununurra (Australia Barat) menggunakan penanda nRFLP (Nuclear Restriction Fragment Length Polymorphysm), memiliki heterozygositas sangat rendah (Ho dan $\mathrm{He}=0,04)$ yang berkorelasi dengan rendahnya variasi kandungan minyaknya. Dengan demikian untuk D. rumphii masih dapat ditingkatkan 
kecepatan pertumbuhan dan kualitas kayu (strip atau garis yang terbentuk pada kayu teras) melalui program pemuliaan. Menurut Standar Nasional Indonesia (SNI), kayu teras eboni yang memiliki strip (garis hitam) lebih dari 10 strip pada lebar bidang radial $10 \mathrm{~cm}$, merupakan kualitas utama (Hendromono \& Allo, 2008).

Keragaman genetik D. rumphii yang terdistribusi lebih banyak didalam populasi $(91,24 \%)$ daripada antar populasi $(8,76 \%)$ berarti seleksi individu yang akan dilibatkan dalam program pemuliaan lebih banyak diambil dari dalam populasi. Karakter penting yang dimuliakan minimal cukup dikendalikan oleh faktor genetik dan memiliki nilai ekonomi (Zobel, \& Talbert, 1984). Kualitas kayu teras adalah karakter penting yang dikendalikan oleh faktor genetik, sehingga karakter ini yang menjadi kriteria dalam melakukan seleksi. Peningkatan variasi genetik pada generasi selanjutnya membutuhkan infusi materi genetik dari populasi atau provenans lainnya, sehingga seleksi dapat dilakukan secara lebih intensif (White, 1987). Materi infusi juga dapat dilakukan melalui persilangan dengan jenis lain yang masih dalam satu marga yang sama.

\section{KESIMPULAN}

Total keragaman genetik D. rumphii dari empat populasi yang diamati sebesar 0,64. Keragaman genetik tersebut sebagian besar terdistribusi didalam populasi yaitu sebesar $91,24 \%$ dan sisanya $8,76 \%$ terdistribusi antar populasi. Terdapat tiga klaster yang menunjukkan hubungan kekerabatan diantara populasi-populasi tersebut yaitu populasi Bitung dan Bolaang Mongondow membentuk klaster pertama, populasi Talise membentuk klaster kedua dan populasi Talaud membentuk klaster ketiga. Nilai indeks fiksasi pada setiap populasi dan lokus yang diamati bernilai positif mengindikasikan bahwa pada semua populasi yang diteliti meskipun memiliki keragaman genetik yang terdistribusi sebagian besar didalam populasi, namun terlihat adanya indikasi terjadi pengurangan heterozigositas.

\section{UCAPAN TERIMA KASIH}

Ucapan terima kasih dan penghargaan yang tinggi kami sampaikan kepada Dr. Ir. Mahfudz, MP, (Kepala Balai Penelitian Kehutanan Manado), Ir. Sudiyono, M.Si (Kepala Balai Konservasi Sumberdaya Alam), Ir. Agus Rante Lembang, M.Si (Kepala Balai Taman Nasional Bogani Nani Wartabone) yang telah banyak memfasilitasi sehingga penelitian ini dapat terlaksana. Penghargaan dan Ucapan terima kasih yang tulus kami sampaikan kepada kepala Laboratorium Pemuliaan Pohon, Fakultas Kehutanan Universitas Gadjah Mada dan staff yang telah membantu dalam pelaksanaan analisis genetik menggunakan penanda Isoenzim. Penghargaan dan terima kasih yang tulus juga disampaikan kepada rekan-rekan tim penelitian eboni di Balai Penelitian Kehutanan Manado yang telah banyak membantu dalam persiapan dan pelaksanaan kegiatan penelitian di lapangan. Ucapan Terima Kasih dan penghargaan yang tinggi juga disampaikan kepada semua pihak yang sudah membantu dalam pelaksanaan penelitian dan tidak dapat kami sebutkan satu per satu.

\section{DAFTAR PUSTAKA}

Alrasyid, H. (2002). Kajian Budidaya Pohon Eboni. Berita Biologi, 6(2). Bogor, Indonesia: Puslit Biologi LIPI.

Butcher, P.A, Moran, G.F, \& Perkins. H.D. (1996). Genetic Resources and Domestication of Acacia mangium. In M.J. Dieters, A.C. Matheson, D.G. Nikles, C. E. Hardwood, \& S. M. Walker (Eds.). Proc. QFRI-IUFRO Conf. Caloundra, Quensland, Australia.

Center for Plant Conservation. (1991). Genetic Sampling Guidelines For Conservation Collection of Endangered Plants. In D.A. Falk \& K.E. Holsinger (Eds.) Genetics and conservation of rare plants. New York: Oxford University Press.

Departemen Kehutanan. (2003). Pengelompokan Jenis Kayu Sebagai Dasar Pengenaan Iuran Kehutanan, Pub. L. No. 163/Kpts-II/2003 (2003). Departemen Kehutanan, Indonesia. 
https://doi.org/10.1017/CBO9781107415324. 004

Hamrick, J. L., \& Godt, M. J. W. (1990). Allozyme diversity in plant species. In Plant population genetics, breeding, and genetic resources. (pp. 43-63). Sunderland, Massachusetts: Sinauer Associates Inc.

Hamrick, J.L. (1993). Genetic Diversity and Conservation in Tropical Forest. In R. M. Drysdale., S.E.T. John, 7 A.C. Yasa (Eds.). Proceeding of The ASEAN-Canada Symposium On Genetic Conservation and Production of Tropical Tree Seed., 1-9 ASEAN-Canada Forest Tree Seed Centre, Muaklek, Saraburi, Thailand.

Hamrick, J.L \& Godt, M.J.W. (1989). Isozyme and The Analysis of Genetic Structure In Plant Population. In D. E. Soltis \& P. S. Soltis (Eds.). Isozyme in Plant Biology. Oregon: Dioscoridos Press.

Hardiyanto, E.B. (2000). Genetik dan Strategi Pemuliaan Acacia mangium. In Seminar Nasional Silvikultur 1999. Peluang dan Tantangan Menuju Produktifitas dan Kelestarian Sumberdaya Hutan Jangka Panjang. Yogyakarta: Fakultas Kehutanan, Universitas Gadjah Mada.

Haryjanto, L. (2009). Keragaman genetik cendana (Santalum album Linn) di Kebun Konservasi Ex-situ Watusipat, Gunungkidul dengan penanda isozim. Jurnal Pemuliaan Tanaman Hutan, 3(3), 127-138. https://doi.org/10.20886/jpth.2009.3.3.127138

Hendromono \& Allo, M.K. (2008). Konservasi Sumberdaya Genetika Eboni Di Sulawesi Selatan. Info Hutan, V(2), 177-187.

Indrioko, S. (1996). Studi Variasi Genetik Pinus merkusii Jungh. Et de Vriese di Pulau Jawa dengan Metode Analisis Isozym (Tesis tidak dipublikasikan). Universitas Gadjah Mada.

Jones, C.G. (2008). The Best of Santalum album: Essentiaal Oil Composition, Biosynthetis and Genetic Diversity in The Australian Tropical Sandalwood Collection (Thesis). Faculty of Natural and Agriculture Science, The University of Western Australia.

Kinho, J. (2014). Status Dan Strategi Konservasi Eboni (Diospyros rumphii Bakh .) Di Sulawesi Utara. In S. W. Manuhara, D. Winarni, Ni'matusahroh, S. Hariyanto \& H. Purnobasuki (Eds.). Seminar Nasional Biodiversitas V"Pemanfaatan dan Konservasi Keanekaragaman Hayati Untuk Kesejahteraan Manusia (pp. 130-137).
Surabaya: Departemen Biologi, Fakultas Sains dan Teknologi Universitas Airlangga.

Lee, S.L., Kevin, K. S., Leng-Guan Saw, Norwati, A., Salwana, M. H. S., Chai-Ting Lee, \& Norwati, M. (2002). Population Genetics of Intsia palembanica (Leguminosae) and Genetic Conservation of Virgin Jungle Reserve in Peninsular Malaysia. American Journal of Botany, 89(3), 447-459.

Lestyaningsih, I., Nai'em, M. \& Winarni, W. W. (2005). Keragaman Genetik Konservasi ExSitu Meranti Merah (Shorea leprosula Miq.) Populasi Sumatera Berdasarkan Analisis Isozim. In Peran Konservasi Sumberdaya Genetik. Yogyakarta: International Tropical Timber Trees \& Fakultas Kehutanan, Universitas Gadjah Mada.

Martawijaya, A., \& Kartasujana, I. (1977). Ciri Umum, Sifat dan Kegunaan Jenis-Jenis Kayu Indonesia. Lembaga Penelitian Hasil Hutan, 41(22\&23).

Moran, G.F., \& Glaubitz, J.C. (2000). Genetic Tools: The Use of Biochemical and Molecular Markers. In A.Young, D. Boshier, \&T. Boyle. (Eds.). Forest Conservation Genetics: Principles and Practice. Australia: CSIRO Publishing.

Na'iem, M. (2001). Genetic variation of Shorea leprosula Miq. In Three Population in Indonesia: Implication for Ex Situ Conservation. Buletin Kehutanan.

Nei M. (1972). Genetic Distance Between Population. American Naturalist, (106), 283-292.

Nei, M. (1973). Analysis of Genetic Diversity in Subdivided Population. In Proceeding of The National Academy of Science. USA: National Academy of Science.

Nei, M. (1987). Moleculer Evolutionary Genetics. New York: Columbia University Press.

Restu, M. (2007). Keragaman Genetik Lima Provenansi Eboni (Diospyros celebica Bakh.) Untuk Pemuliaan Pohon dan Konservasi Genetik (Disertasi tidak dipublikasikan). Program Pascasarjana, Universitas Hasanudin, Makassar.

Seido, K. (1993). Manual of Isozyme Analysis. Jakarta: JICA and Directorate General of Reforestation and Land Rehabilitation, Ministry of Forestry in Indonesia.

Sunaryo. (2002). Konservasi Eboni (Diospyros celebica Bakh.). Berita Biologi, 6(2). Bogor, Indonesia: Puslit Biologi LIPI. 
White T.L. (1987). A Conceptual Framework For Tree Improvement Programs. New Forest, 4, 325-342.

Widyatmoko, AYPBC. (2006). Strategi Konservasi Ulin Berdasarkan Informasi Keragaman Genetik. In A.Y.P.B.C. Widyatmoko \& M. Susanto. (Eds.). Workshop Sehari Peran Litbang Dalam Pelestarian Ulin (pp. 141148). Samarinda, Indonesia: Pusat Penelitian dan Pengembangan Hutan Tanaman dan Tropenbos International Indonesia.

Widyatmoko AYPBC., Nurtjahjaningsih ILG., \& Prastyono. (2011). Study On The Level Of Genetic Diversity of Diospyros celebica, Eusideroxylon zwagery and Michelia spp. Using RAPD Markers (No. ITTO Project PD 539/09 Rev.1 (F)).
Yeh, F.C. (2000). Population Genetics. In A. Young, D. Boshier, \& T. Boyle. (Eds.). Forest Conservation Genetics: Principle and Practice. CABI Publishing.

Yudohartono, T.P. (2008). Studi Variasi Genetik Beberapa Populasi Merbau (Intsia bijuga O.Ktze) Menggunakan Penanda Isoenzim dan Pemanfaatannya Dalam Program Konservasi Genetik (Tesis tidak dipublikasikan). Fakultas Kehutanan, Universitas Gadjah Mada.

Zobel B, \& Talbert J. (1984). Applied Forest Tree Improvment. New York, Chichester, Brisbane,Toronto,Singapore: John Willey \& Sons. 
Jurnal Pemuliaan Tanaman Hutan

Vol. 10 No. 2, Desember 2016, p. 95 - 109 